\title{
Immigrant Presence, Group Boundaries and Support for the Welfare State in Western European Societies
}

Nate Breznau, Mannheim Centre for European Social Research (MZES) (breznau.nate@gmail.com) Nate is primary contact.

Maureen A. Eger, Department of Sociology, Umeå University (maureen.eger@ soc.umu.se)

This is the preprint version of the article now appearing in Acta Sociologica. https://doi.org/10.1177/0001699316645168

Users may access all code and technical details here: https://drive.google.com/file/d/0B4x8ukGR_B9lclg3dGJoMmJ6d3c/view

\begin{abstract}
The intersection of group dynamics and socioeconomic status theories is applied as a framework for the puzzling relationship of immigration and support for the welfare state in Western Europe. Group dynamics theories suggest that how individuals define their group boundaries moderates the impact of immigration on support for the welfare state. Immigrant presence should have the strongest effects for those with exclusive national group boundaries; weaker for those with conditionally inclusive boundaries based on reciprocity; and weakest or non-existent for those with inclusive group boundaries. Group boundaries should interact with material self-interest leading individuals with less material security who are more likely to face social risks to be more supportive of the welfare state. Using data from the 4th European Social Survey linked to regional and national data we find that group boundary salience plays a large moderating role in the relationship of immigration and native support for the welfare state, and that this role is intricately linked to material self-interest. Group dynamics should therefore be viewed in conjunction with existing structural welfare state theories as opposed to an alternative or isolated mechanism.
\end{abstract}




\section{A. WeLFARE StATES AND IMMIGRATION}

The national welfare states in Western European countries are often a source of citizen pride (Evans and Kelley, 2002). The success of these societies at staving poverty and inequality compared to others is difficult to deny (Brady, 2009; Kenworthy, 2004). They also serve as model systems for European Union membership (Pierson and Leibfried, 1995). Yet their sustainability potentially wanes under permanent austerity and the dramatic rise of immigration. Western European countries now are more ethnically and culturally diverse than at any point in their respective histories (Castles and Miller, 2003). Rising immigration coincides with a peak and decline in overall welfare spending across these countries, most notably in ideal-typical Sweden (OECD, 2012). Immigration may be a catalyst for this.

The burning question is whether immigration reduces commitment to welfare policies in Europe as does racial-ethnic diversity in the United States (Fox, 2004; Luttmer, 2001). Some Swedeish studies suggest this is the case (Eger 2010; Dahlberg, Edmark, and Lundqvist 2012). However, a number of cross-national studies suggest that it is not (Brady and Finnigan, 2014; Hjerm and Schnabel, 2012; Mau and Burkhardt, 2009). Some even find that immigration increases support among certain individuals (Burgoon, Koster, and van Egmond 2012). These ambiguous results call for further consideration of this topic.

Previous research identifies two general modes for immigration to shape support for the welfare state as discussed in the following sections. One is theories of group dynamics suggesting that immigrants threaten and in turn activate salience of group boundaries leading to reduced native willingness to distribute resources. Another is that the need for material security motivates support for the welfare state. We argue that these two theoretical propositions most likely interact. Thus support for the welfare state depends on how individuals define group boundaries and their material securities.

\section{A.1 The Salience of Group Boundaries}

The unprecedented levels of foreign-born persons in Western Europe may lead to an enhanced native-born awareness of group boundaries existing between them and various immigrant groups. This may lead natives to change or re-orient policy preferences to defend what they perceive as their native group's own resources, or as an abandonment of solidarity with a national group that does not fit their ideal subjective composition. This theoretical framework of group dynamics is often invoked to explain immigration and political attitudes (Finseraas, 2012; Mau and Burkhardt, 2009). 
According to permutations of social identity theory, individuals categorize the world into social groups and identify to which they belong (Allport, 1954; Festinger, 1954; Tajfel, 1970). Belonging requires defining different groups based on their compositions (see review by Lamont and Molnár, 2002). Increased presence of out-group members motivates in-group members to clearly define and defend who is in versus out of the group (Tajfel and Turner, 1979; Turner, 1975).

In-group members prefer to allocate their perceived in-group resources to their own subjectively defined group members. When this is not possible, in-group members may abandon group sharing to the detriment of both subjectively defined in- and out-group members (Brewer, 1979; Mullen et al., 1992; Tajfel, 1982; Tajfel et al., 1971). This logic applies to immigrant presence and welfare state distribution in Western Europe. If natives subjectively exclude immigrants from their in-groups then they theoretically will stop supporting the welfare state for everyone as either a way to prevent resource movement toward the out-group as immigrants tend to be net beneficiaries as opposed to contributors (Boeri, 2010), or as a lack of solidarity with a group that does not fit their subjective ideals (discussion in Bay and Pedersen 2006, p. 422).

Native-born is a broad category but it implies a birth-right attachment to a national group whose boundaries give a sense of individual belonging in a world of groups competing for legitimacy, power and resources (Brubaker, 1996). Natives tend to percieve themselves as entitled to distributive justice and welfare protection as members of a subjective national in-group (Arts and Gelissen, 2001; Taylor-Gooby, 2011). National group boundaries often subordinate other potentially immigrant-salient boundaries such as family, class, religion and ethnicity due to the overwhelming symbolic-rhetorical, legal and militaristic power of nation states (Kaufmann, 2008; Renan, 1882). The national-level is also where the largest share of welfare state resources are collected and distributed.

We thus focus on national subjective group boundaries. There are at least two types of exclusive group boundaries, usually drawn along ethnic and civic, or just civic dimensions (Putnam, 2007; Reeskens and Wright, 2013) and either prefer full or partial exclusion of immigrants. Often those wholly exclusive persons see immigrants as not ethnically or civically fitting with their subjective national in-groups. Conditionally exclusive persons focus on immigrants' abilities to act according to national group maxims (regardless of ethnicity). A third, opposing type are those who are inclusive. For example, some individuals define group boundaries as (supra)national and inclusive of all humans (Habermas, 2003; Mau et al., 2008). Although simplified, this tripartite typology offers exemplary differences in subjective group boundary definitions among natives useful for studying group dynamics. Under conditions of greater immigrant presence, the degree of 
exclusivity of individuals' group boundaries should shape their attitudes; (Brewer, 1979; Hogg and Turner, 1987; Tajfel et al., 1971).

Thus we derive hypotheses based on these three types. Those who are strictly exclusive, similar to ethno-civic national identities, should have intense in-group bias where there is greater immigrant presence within their national boundaries. Those who are conditionally exclusive, similar to a civic national identity, should have increased in-group bias but not as dramatic. Finally, natives who define immigrants as part of their in-groups without reservation have inclusive boundaries, not unlike cosmopolitans who are open to a globally or supra-nationally defined group. They should have boundaries that are not salient or even non-existent under greater national immigrant presence. Dividing the population into these three broad types of natives allows us to frame group boundary as a moderator in the hypothesized effect of immigration on support for the welfare state leading to the following:

H1: Exclusive. Group boundaries subjectively excluding immigrants show the largest...

$\mathrm{H} 2$ : Conditionally Inclusive. Group boundaries subjectively conditional on the immigrants lead individuals to a moderate...

H3: Inclusive. Defining groups as inclusive of immigrants has no...

...impact of greater country-level immigrant presence on support for the welfare state.

The salience of group boundaries should also moderate the impact of immigration at the regionallevel where the opportunity for intergroup contact increases and this should further increase the salience of group boundaries because this contact increases comparison and shapes native identity processes (Reicher, 2004). The sub-national level is also preferable because it yields a greater number of geographic cases to analyze, and has proven fruitful elsewhere (Eger, 2010; Hjerm, 2009). Therefore we expect H1 through H3 to apply to the regional-level.

\section{A.2 Material Self-Interest}

As long demonstrated in welfare state research, attitudes are highly contingent upon individual access to material security (Dallinger, 2010; Hasenfeld and Rafferty, 1989). Less access to materials equates with higher social risk and more to gain from welfare, while greater access to materials means more to lose (e.g. in taxes). This material self-interest hypothesis posits that those lower in socioeconomic status (SES) are more supportive of the welfare state (Bean and Papadakis, 1998; Breznau, 2010; Jæger, 2006; Svallfors, 1997). 
Individuals having much less, i.e., who are to fending for the most basic needs of food and shelter, should face trade-offs with subjective group boundary salience. Those with exclusive boundaries might not be able to afford to lose welfare state protection and thus cannot reduce support merely to punish immigrants or as an expression of lost national group solidarity. This conflict is more difficult to reconcile into a coherent preference for social policy for those lower in SES (Bobo and Licari, 1989) who often lack political capital (Bourdieu, 1984), i.e. they are the most tenuous and susceptible to change given material risks. A survey-experimental Norwegian study demonstrates this with attitudes toward a minimum income policy: after being asked if they still support minimum income when it applies equally to non-Norwegian immigrants, the lower the respondents were in SES (i.e. the less access to material security on average) the more likely they were to change an initial supportive attitude into an unsupportive attitude (Bay and Pedersen, 2006), whereas those higher in education tended to stick to their initial policy position. Thus, material security is a kind of trump card against the impact of immigration:

H4a: The negative impact of socioeconomic status on support for the welfare state will be largest for individuals in the strictly exclusive of immigrants category.

However, for those who are less at material risk, the impact of immigration should be greatest (i.e. uninterrupted by self-interest). Given our three subjective boundaries, we would expect this great impact to only exist for those who already define immigrants outside of their group. Thus,

H4b: The negative impact of immigrant presence on support for the welfare state will be largest for those in the exclusive category with higher socioeconomic statuses.

Material self-interest extends to social context as well as individual conditions. We expect regions that are the most economically depressed will have greater support for the welfare state net of individual SES. Labor markets are also organized regionally and when immigrant presence increases, competition for jobs often follows, leading to a destabilization of wages and employment (Nannestad, 2007). Burgoon, Koster and van Egmond (2012) demonstrate this phenomenon where a greater share of foreign-born in a specific occupation leads the workers to be more supportive of the welfare state out of need.

H5: Regions that are poorer contain individuals who are more supportive of the welfare state. 
Because of H1 we expect this effect to be particularly pronounced for those in the exclusive category because they should otherwise have the lowest support under greater immigrant presence, i.e. creating the largest discrepancy between group boundaries and material needs.

\section{B. DATA AND Methods}

To test our hypotheses, we utilize data from the $4^{\text {th }}$ European Social Survey (ESS, 2008) with a welfare state module and representative regional-level samples. We use 14 Western European countries in the survey with Germany split into two for a total of 24,604 individuals in 105 regions within 15 societiesi; we refer to these as "countries" for ease of discussion.

\section{B.1 Measuring Support of the Welfare State}

We measure our dependent variable support for the welfare state using 6 ESS questions asking about the role of the government in providing for basic needs and insurance against social risks, e.g., health care, pensions, and unemployment. These items have theoretical face value, and form one major welfare attitude (Roosma et al., 2014). We use a second dimension of welfare policy outcomes as an independent variable measured from 5 ESS questions that measure quality assessment of current welfare provisions.

Following Davidov and colleagues (2012), we conclude that throwing a bunch of welfare state related questions into one scale and generating a latent variable may not be the best practice. First, welfare attitude questions are shown to be a product of various latent attitudes (van Oorschot and Meuleman, 2012). Second, there is known to be a bias in support for the welfare state by individual evaluations of its current performance (Roosma et al., 2013). This is an argument of political attitude theories where an individual's absolute preferences for government welfare provisions are biased by current levels of provisions (Wlezien, 1995; Blekesaune and Quadagno, 2003). Thus support for the welfare state and welfare policy outcomes are captured in a structural measurement model to correct this bias to some degree, following the concepts outlined in Roosma et al. (2013). Our descriptives (Table 3) and multilevel linear models (Table 4) refer only to predicted factors taken from the results of the measurement model whose structural loadings are presented in Table 1. 
Table 1. Support for the Welfare State Measurement Items, European Social Survey 2008

\begin{tabular}{|c|c|c|c|c|c|c|}
\hline Observed Variables & $\mathrm{N}$ & Mean & S.D. & $\operatorname{Min}(b y) \operatorname{Max}$ & \multicolumn{2}{|c|}{ Factor Loadings $^{\mathrm{a}}$} \\
\hline Role of government to: & & & & & $\begin{array}{l}\text { Support of the } \\
\text { Welfare State }\end{array}$ & $\begin{array}{c}\text { Welfare Policy } \\
\text { Outcomes }\end{array}$ \\
\hline Ensure adequate health care & & & & $0(1) 10$ & 0.586 & -0.119 \\
\hline Ensure standard of living for old & & & & $0(1) 10$ & 0.730 & -0.030 \\
\hline Ensure jobs for all & & & & $0(1) 10$ & 0.767 & -0.079 \\
\hline Ensure standard of living for unemployed & & & & $0(1) 10$ & 0.656 & -0.083 \\
\hline Ensure child care for workers & & & & $0(1) 10$ & 0.652 & -0.064 \\
\hline Provide paid care leave & & & & $0(1) 10$ & 0.653 & -0.035 \\
\hline \multicolumn{7}{|l|}{ Quality of welfare in: } \\
\hline Health care & & & & $0(1) 10$ & 0.047 & 0.501 \\
\hline Standard of living for pensioners & & & & $0(1) 10$ & 0.117 & 0.620 \\
\hline Job opportunies for young workers & & & & $0(1) 10$ & 0.131 & 0.609 \\
\hline Standard of living for unemployed & & & & $0(1) 10$ & -0.047 & 0.531 \\
\hline Child care for workers & & & & $0(1) 10$ & 0.077 & 0.600 \\
\hline \multicolumn{7}{|l|}{ Latent Policy Preferences } \\
\hline Support for the Welfare State ${ }^{b}$ & & & & & 1.000 & -0.171 \\
\hline Welfare Policy Outcomes ${ }^{b}$ & & & & & -0.171 & 1.000 \\
\hline
\end{tabular}

${ }^{\mathrm{a}}$ Factor loadings from exploratory measurement model; bottom two rows are the correlations between predicted factor scores

${ }^{\mathrm{b}}$ Predicted latent variables from a confirmatory structural measurement model. Roosma, van Oorscot and Gelissen (2014) use this same ESS 2008 data to demonstrate that these two factors are scalar invariant across our same countries except Greece. We find that they are also scalar invariant across our groups in Table 2 (see author's online appendix).

\section{B.2 Measuring Immigrant Presence}

We identify immigrant presence as rates of foreign-born persons by country and by subnational region. Immigrant presence increases the visibility of immigrants directly in an individual's region and indirectly via the public sphere (Brader et al., 2008; Price, 1989), thus media and political discussion should lead to an impact of country-level immigrant presence for individuals who live in areas where there are none, few or many immigrants alike. Our country-level measure of percent foreign-born comes from the OECD (2009), and we interpolate the division between East and West German data using regional measures.

We construct our own cross-regional database of percent foreign-born along NUTS divisions within countries $^{\mathrm{ii}}$. The ESS representatively sampled these regions. Although there are other potential measures of immigrant presence such as percent foreign, ethnic fractionalization or percent Muslim for example, it is first generation immigrants of any source that are the most likely to appear, behave and speak differently than natives. Furthermore, this is the only available directly comparable regional measure. 


\section{B.3 Measuring Group Boundaries}

Investigating immigration impacting support for the welfare state via group boundary salience requires identification of the specific subjective boundaries that each individual uses to define the national in-group and its resources. To do this we use the ESS question asking if and when an immigrant should get the same social benefits as natives (see Table 2). At one extreme we identify group boundaries that are inclusive of immigrants. We use either the first or second answer categories as evidence of inclusive boundaries because these individuals prefer to extend social rights immediately or without reciprocity from immigrants. At the other extreme we identify exclusive boundaries characterizing those who would never extend social benefits to immigrants based on the second to last category. They define their subjective national in-group boundaries as closed to nonnatives. The other two middle categories identify those with group boundaries conditionally inclusive based on reciprocity of immigrants. Some answered "don't know" to this question, but the case numbers are few so we dropped them.

\footnotetext{
${ }^{i}$ Austria, Belgium, Denmark, Finland, France, Greece, Ireland, The Netherlands, Germany (former East and West separately), Norway, Spain, Switzerland, Sweden, the United Kingdom.

ii We collected this data by hand from national censes (see Appendix Table 1).
} 
Table 2. Measuring Group Boundaries through the ESS Question on Social Rights for Immigrants

Thinking of people coming to live in [country] from other countries, when do you think they should obtain the same rights to social benefits and services as citizens already living here?

Response Group Basis $\quad$ N $\quad$ Group Boundary Definition

\begin{tabular}{|c|c|c|c|}
\hline $\begin{array}{l}\text { Immediately on arrival } \\
\text { After living in [country] for a year, } \\
\text { whether or not they have worked }\end{array}$ & Inclusive & $\begin{array}{l}2,596 \\
2,885\end{array}$ & $\begin{array}{l}\text { Immigrants granted access to in-group benefits } \\
\text { and services with or without contributing; } \\
\text { group boundary open }\end{array}$ \\
\hline $\begin{array}{l}\text { Only after they have worked and paid } \\
\text { taxes for at least a year } \\
\text { Once they have become a [country] } \\
\text { citizen }\end{array}$ & Conditionally Inclusive & $\begin{array}{l}11,753 \\
8,419\end{array}$ & $\begin{array}{l}\text { Immigrants granted access conditional upon } \\
\text { material or civic contribution to the in-group; } \\
\text { boundary fickle }\end{array}$ \\
\hline They should never get the same rights & Exclusive & 1,718 & $\begin{array}{l}\text { Immigrants excluded from in-group benefits } \\
\text { and services; } \\
\text { boundary closed }\end{array}$ \\
\hline Don't know & unknown & 788 & Respondent does not define boundary \\
\hline
\end{tabular}

NOTE: ESS Data, Round 4 (2008-2010); 14 countries surveyed in Western Europe 
As the group boundaries question refers to social benefits, it may be endogenous with our dependent variable and our independent variable welfare policy outcomes, i.e. that different types of welfare attitudes are also expressed in response to the group boundary question. In order to check that this is not the case we test the measurement of our dependent variable separately for each type of group boundary; put in statistical terms we look for measurement invariance by group (van de Schoot et al., 2012). To do this we first run a model where all parameters are free to vary by group. This model sets a comparative baseline fit (based on RMSEA, AIC, BIC, CFI and TLI; see author's online appendix). We then constrain the freely estimated factor loadings each to be equal across the three groups, leaving the means and variances to vary. This model fits slightly better. Finally, we fix all parameters to be equal across all groups, and this model does not fit well at all. Given that we have scalar invariance across groups, we conclude that individuals in these three groups have similarly constructed attitudes toward the welfare state and this construct does not pattern or correlate with these group boundaries, thus we have evidence against endogeneity. However if there is endogeneity, then this should reduce the impact of our immigration variable due to collinearity between it and categorical group boundaries. If anything this should make an impact of immigrant presence harder to identify and our tests more conservative.

\section{B.4 Measuring Material Self-Interest}

Education, occupation and income are the typical markers of socioeconomic status (SES). However, they are difficult to disentangle even when we have thousands of cases (Ganzeboom et al., 1992). We measure education in years, and proxy class via a linear occupational status measure (Kelley, 1990) and dichotomous variables for supervisor of workers and capitalist owners with employees. We take these measures despite their collinearity, and do not argue for priority of one over others. Essentially all are markers of material self-interest, and we do not seek to uncover exactly what drives this. We omit income as it introduces a large missing data problem, and it probably is not missing at random leaving us with a more accurate chance of measuring socioeconomic positions of individuals using occupation and education. Moreover, with $28 \%$ missing on income in the ESS, imputation likely will attenuate the impact of income and inflate the impact of other SES and demographic regressors (Landerman et al., 1997).

Finally, we control for individuals who are vulnerable to social risks because they were unemployed or on sick leave from work in the last 7 days, and thus have self-interest in supporting the welfare state (Pfeifer, 2009). 


\section{B.5 Independent Variables}

In addition to SES, demographics are the other most common explanatory variables for welfare state attitudes (Arts and Gelissen, 2001; Bean and Papadakis, 1998; Svallfors, 1997; TaylorGooby, 2001). Based on this research we use the following essential controls. Females are more supportive on average. Older and younger persons are more supportive alike and thus we take age and age-squared ${ }^{\text {iii }}$. We also utilize subjective left-right to control for the known overlap between partisan or political ideology and welfare policy preferences (Huber, 1989). At the regional- and country-levels, we measure gross domestic product $(G D P)$ per capita at parity and the employment rate as a percent of the labor force to identify the material resources necessary to provide and potential need of welfare across regions and countries (Eurostat, 2014; OECD, 2009).

iii Although this allows for an inverse "U" shaped curve and provides interesting life course changes in support for the welfare state decreasing at a certain age or time, we use it here primarily as a control that more accurately reflects the effect of age than most models which simply use age linearly. 
Table 3. Descriptive Statistics for All Variables Analyzed in the Multilevel Linear Models and by Group

\begin{tabular}{|c|c|c|c|c|c|c|c|c|c|c|c|}
\hline \multicolumn{4}{|l|}{ Individual-Level } & \multicolumn{2}{|c|}{$\begin{array}{c}\text { Overall } \\
N=24,604\end{array}$} & \multicolumn{2}{|c|}{$\begin{array}{l}\text { Exclusive } \\
N=1,621\end{array}$} & \multicolumn{2}{|c|}{$\begin{array}{l}\text { Conditionally Inclusive } \\
\qquad N=18,253\end{array}$} & \multicolumn{2}{|c|}{$\begin{array}{l}\text { Inclusive } \\
N=4,730\end{array}$} \\
\hline Variable & Measure & Min & Max & Mean & S.D. & Mean & S.D. & Mean & S.D. & Mean & S.D. \\
\hline Support of the Welfare State ${ }^{a}$ & see Table 1 & -4.92 & 1.70 & -0.01 & 1.00 & 0.04 & 1.24 & -0.04 & 0.98 & 0.08 & 0.98 \\
\hline Female & (male) & 0 & 1 & 0.52 & 0.50 & 0.54 & 0.50 & 0.51 & 0.50 & 0.53 & 0.50 \\
\hline Age & in years & 15 & 85 & 47.74 & 17.90 & 50.13 & 17.76 & 48.01 & 17.98 & 45.86 & 17.47 \\
\hline Subjective Left-Right $^{c}$ & political orientation & 0 & 10 & 5.00 & 1.97 & 5.35 & 2.10 & 5.11 & 1.93 & 4.47 & 2.00 \\
\hline Welfare Policy Outcomes $^{\mathrm{a}}$ & see Table 1 & -4.92 & 1.70 & -0.01 & 1.00 & 0.04 & 1.24 & -0.04 & 0.98 & 0.08 & 0.98 \\
\hline Education $^{c}$ & in years & 0 & 23 & 12.70 & 3.95 & 10.99 & 3.63 & 12.66 & 3.89 & 13.42 & 4.10 \\
\hline Occupational Status $^{c}$ & linear (Kelley 1990) & 0 & 10 & 4.59 & 2.49 & 3.52 & 2.06 & 4.58 & 2.47 & 4.99 & 2.58 \\
\hline Capitalist & self-emp. w/ employees & 0 & 1 & 0.05 & 0.21 & 0.05 & 0.22 & 0.05 & 0.22 & 0.04 & 0.19 \\
\hline Supervisor & of others on the job & 0 & 1 & 0.30 & 0.46 & 0.23 & 0.42 & 0.31 & 0.46 & 0.30 & 0.46 \\
\hline Vulnerable & sick or unemp. past 7 days & 0 & 1 & 0.29 & 0.45 & 0.38 & 0.48 & 0.29 & 0.46 & 0.25 & 0.43 \\
\hline Regional-Level $^{b}$ & $N=105$ & & & & & & & & & & \\
\hline Foreign-born & $\%$ & 1.98 & 37.16 & & & & & & & & \\
\hline GDP & per capita; in $\mathrm{k} €$ & 14.90 & 120.60 & & & & & & & & \\
\hline Employment Rate & employed as \% of LF & 53.97 & 81.63 & & & & & & & & \\
\hline Country-Level & $N=15$ & & & & & & & & & & \\
\hline Foreign-born & $\%$ & 4.10 & 26.90 & & & & & & & & \\
\hline GDP & per capita; in $\mathrm{k} €$ & 20.96 & 87.20 & & & & & & & & \\
\hline Employment Rate & employed as \% of LF & 58.77 & 79.70 & & & & & & & & \\
\hline
\end{tabular}




\section{B.6 Methods}

We use a three-level general linear regression model to predict support for the welfare state. We see group boundaries as moderating the impact of immigrant presence on welfare state attitudes (H1-H3) and group boundaries as interacting with SES at both the group-level (H4a) and at the country-level (H4b). We run this as a multigroup model taking the focus away from comparison with an overall population mean and interaction terms, to a regression to the mean of each group with fixed and varying coefficients by group. We do, however, employ a cross-level interaction with education and country-level foreign-born.

All individual-level variables are grand mean centered. For regional and country-level variables we standardize $\mathrm{x}$-variables at their respective levels which allow us to test for the relative impact of immigrant presence, GDP and employment rate (Andreß et al., 2013). As long noted by social researchers, both the salience of group boundaries and the effect of material self-interest are subject to social comparison. Individuals compare their current situations to the situations of others within their contexts (Festinger, 1954). It is important to note that standardized measures may only be interpreted in comparison to the variance at each level, so a net effect of 0.50 for a regional-level variable is large, but the gross size is relative to the amount of the total variance that takes place at that level which we will show is small (>4\%) in the case of the regional level (Hox, 1995). Our main goal is not to determine what explains the most, but to test for significant effects.

If group boundaries moderate the effects of independent variables we expect that the addition of our three group boundaries as parameters in our multilevel regression leads to a better empirical model of the dependent variable. This can be tested with the $\mathrm{chi}^{2} / \mathrm{df}$ test, model selection criteria of AIC offering a measure of the tradeoff between fit and complexity, and with slope tests comparing the coefficients and standard errors (as with a t-test) between groups to determine if slopes are significantly different (Baron and Kenny, 1986; Pedhazur, 1997).

If the salience of group boundaries explains the relationship between immigration and attitudes, we should see that the effect of immigrant presence will be greatest for those whose group boundaries are most exclusive of immigrants; i.e. the category we label exclusive. If the effect of immigration on welfare attitudes does not differ across groups, then the theoretical mechanism of group boundary salience does not appear responsible for the relationship. We can test this by running models in sequence that add variance-components and variables in stages and then compare them following this order: 
MO. Empty-model with intercepts (i.e. means) allowed for individuals, regions, and countries.

M1. Intercepts and errors in M0 are allowed to vary across our three groups.

M2. All individual-level variables added to M1 but constrained to equal coefficients (effects) across groups.

M3. Regional and country foreign-born, GDP and unemployment added to M2 constrained across groups.

M4. Percent foreign-born, GDP and unemployment vary by group. Formally tests H1, H2, H3 and $\mathrm{H} 5$.

M5. The coefficients for individual self-interest variables vary by group. Formally tests H4a.

M6. An interaction within each group for education and country foreign-born. Formally tests H4b.

\section{Results}

Table 4 demonstrates the size and significance of standardized independent variable coefficients predicting our latent measure of support for the welfare state by group. The exclusive category is presented in the first 4 columns, conditionally inclusive the next and inclusive last. Coefficients constrained to be equal across group are set in standard typeface and coefficients that vary by group in bold. 
Table 4. Multigroup, Multilevel Linear Models Predicting Support for the Welfare State

\begin{tabular}{|c|c|c|c|c|c|c|c|c|c|c|c|c|}
\hline \multirow{2}{*}{$\begin{array}{l}\text { Group Boundary-> } \\
\text { Variable }^{a}\end{array}$} & \multicolumn{4}{|c|}{ Exclusive } & \multicolumn{4}{|c|}{$\underline{\text { Conditionally Inclusive }}$} & \multicolumn{4}{|c|}{$\underline{\text { Inclusive }}$} \\
\hline & M3 & M4 & M5 & M6 & M3 & M4 & M5 & M6 & M3 & M4 & M5 & M6 \\
\hline Education & $-0.01^{* * *}$ & $-0.01^{* * *}$ & $-0.03^{* * *}$ & $-0.04^{* * *}$ & $-0.01^{* * *}$ & $-0.01^{* * *}$ & $-0.01^{* * *}$ & $-0.01^{* * *}$ & $-0.01^{* * *}$ & $-0.01^{* * *}$ & 0.00 & 0.00 \\
\hline \multirow[t]{2}{*}{ Occupational Status } & $-0.02 * * *$ & $-0.02 * * *$ & -0.03 * & -0.03 * & $-0.02 * * *$ & $-0.02 * * *$ & $-0.02 * * *$ & $-0.02 * * *$ & $-0.02 * * *$ & $-0.02 * * *$ & 0.00 & 0.00 \\
\hline & 0.00 & 0.00 & 0.01 & 0.01 & 0.00 & 0.00 & 0.00 & 0.00 & 0.00 & 0.00 & 0.01 & 0.01 \\
\hline \multirow[t]{2}{*}{ Capitalist } & $-0.12 * * *$ & $-0.12 * * *$ & 0.07 & 0.08 & $-0.12 * * *$ & $-0.12 * * *$ & $-0.15^{* * *}$ & $-0.15 * * *$ & $-0.12 * * *$ & $-0.12 * * *$ & -0.04 & -0.04 \\
\hline & 0.03 & 0.03 & 0.11 & 0.11 & 0.03 & 0.03 & 0.03 & 0.03 & 0.03 & 0.03 & 0.07 & 0.07 \\
\hline \multirow[t]{2}{*}{ Supervisor } & -0.03 * & -0.03 * & -0.02 & -0.02 & -0.03 * & -0.03 * & -0.02 & -0.02 & -0.03 * & -0.03 * & $-0.07^{*}$ & -0.07 * \\
\hline & 0.01 & 0.01 & 0.06 & 0.06 & 0.01 & 0.01 & 0.02 & 0.02 & 0.01 & 0.01 & 0.03 & 0.03 \\
\hline \multirow[t]{2}{*}{ Vulnerable } & $0.08^{* * *}$ & $0.08^{* * *}$ & -0.02 & -0.01 & $0.08^{* * *}$ & $0.08^{* * *}$ & $0.09 * * *$ & $0.09 * * *$ & $0.08^{* * *}$ & $0.08 * * *$ & 0.06 & 0.06 \\
\hline & 0.02 & 0.02 & 0.05 & 0.05 & 0.02 & 0.02 & 0.02 & 0.02 & 0.02 & 0.02 & 0.03 & 0.03 \\
\hline Group intercept & -0.22 & -0.24 & -0.26 & -0.26 & -0.10 & -0.11 & -0.11 & -0.11 & 0.00 & 0.00 & 0.00 & 0.00 \\
\hline \multirow[t]{2}{*}{ Regional Foreign-born } & $-0.08 * *$ & 0.06 & 0.07 & 0.07 & -0.08 ** & -0.08 ** & -0.08 ** & $-0.08 * *$ & $-0.12^{* * *}$ & $-0.12 * * *$ & $-0.13^{* * *}$ & $-0.13^{* * *}$ \\
\hline & 0.03 & 0.05 & 0.05 & 0.05 & 0.03 & 0.03 & 0.03 & 0.03 & 0.03 & 0.03 & 0.03 & 0.03 \\
\hline Regional GDP & 0.03 & 0.05 & 0.05 & 0.05 & 0.03 & 0.03 & 0.03 & 0.03 & 0.03 & 0.03 & 0.03 & 0.03 \\
\hline \multirow[t]{2}{*}{ Regional Employment rate } & -0.04 * & -0.01 & 0.00 & 0.00 & -0.04 * & -0.03 & -0.03 & -0.04 * & -0.08 ** & $-0.08 * *$ & $-0.08 * * *$ & $-0.08 * *$ \\
\hline & 0.02 & 0.03 & 0.03 & 0.03 & 0.02 & 0.02 & 0.02 & 0.02 & 0.02 & 0.02 & 0.02 & 0.02 \\
\hline \multirow[t]{2}{*}{ Country Foreign-born } & $-0.20 * * *$ & $-0.40 * * *$ & $-0.39 * * *$ & $-0.45^{* * *}$ & $-0.20 * * *$ & $-0.19 * * *$ & $-0.19 * *$ & $-0.19 * *$ & $-0.20 * *$ & $-0.20 * *$ & $-0.20 * *$ & $-0.20 * *$ \\
\hline & 0.07 & 0.08 & 0.08 & 0.08 & 0.07 & 0.07 & 0.07 & 0.07 & 0.07 & 0.07 & 0.07 & 0.07 \\
\hline \multirow[t]{2}{*}{ Country GDP } & 0.09 & 0.05 & 0.06 & 0.08 & 0.09 & 0.10 & 0.10 & 0.10 & 0.07 & 0.07 & 0.07 & 0.07 \\
\hline & 0.08 & 0.09 & 0.09 & 0.09 & 0.08 & 0.08 & 0.08 & 0.08 & 0.08 & 0.08 & 0.08 & 0.08 \\
\hline \multirow[t]{2}{*}{ Country Employment rate } & -0.14 & -0.13 & -0.12 & -0.13 & -0.14 & -0.16 & -0.16 & -0.16 & -0.08 & -0.08 & -0.08 & -0.08 \\
\hline & 0.09 & 0.09 & 0.09 & 0.09 & 0.09 & 0.09 & 0.09 & 0.09 & 0.09 & 0.09 & 0.09 & 0.09 \\
\hline Country Foreign-born & & & & $-0.03 * * *$ & & & & 0.00 & & & & $0.01^{*}$ \\
\hline *Individual Education & & & & 0.01 & & & & 0.00 & & & & 0.00 \\
\hline
\end{tabular}

NOTE: ${ }^{*} p<0.05^{* \star}<0.01^{* * *} 0.001$; individual variables grandmean centered; regional variables are within-country-mean centered and then divided by within-country-s.d.; country-variables

centered and divided by across-country-s.d. Coefficients in standard typeface are constrained to be equal across groups; coefficients in bold are allowed to vary. Models $0,1 \& 2$ omitted to save space (for fit statistics see Table 5).

${ }^{a}$ As they are intendend to be control varaibles we do not show results for the variables age, age ${ }^{2}$, subjective left-right, and welfare policy outcomes in order to save space; These variables are present in Models 3-6. 
In Table 4 we omit Models 0-2 but report their fit statistics as baselines for comparison in Table 5. Also, we do not report demographic and control variable effects to keep the focus on our hypotheses. We first see the impact of SES starting with M3. For every year of education individuals across all groups are -0.01 standard deviations less supportive of welfare. Those who are one-point higher (out of 10) in their occupational status are -0.02 less supportive. Those who are petty bourgeoisie are -0.12 less, and so on. All effects in this and the following models may be understood in this way as the dependent variable is also standardized. Generally, those who have less material security due to lower education, income, occupation status or current employment status (vulnerable) are more supportive of welfare. M3 also gives first evidence of regional- and country-level effects. For all groups, in regions where there is one-standard deviation more immigrants than the country's average, individuals are -0.08 individual-level standard deviations less supportive of the welfare state; this might be labeled a large effect if we extrapolate this impact to the regional-level it explains over half of the nevertheless small regional variance in individual support for the welfare state. Individuals who live in countries that are one-standard deviation above the Western European mean on immigration are -0.20 standard deviations less supportive. Measures of regional and national GDP have no impact, but regions with more employment have less support on average.

Next we test group dynamics. M4 shows whether the effect of immigration is greater for those whose group boundaries should become more salient under increased immigrant presence (H1H3). Our first result counters our hypotheses. The impact of regional percent foreign-born is not significant for the exclusive category. There is a negative and significant impact for both conditionally inclusive and inclusive to the degree of -0.08 and -0.12 . However, at the country-level the impact of percent foreign-born confirms our predictions for the exclusive category with a very large -0.40 coefficient. Thus, in a country with one-standard deviation higher immigrant presence residents are nearly half-a-standard deviation less supportive of the welfare state, independent of GDP and regional and individual-effects. The size of this effect is less for the conditionally inclusive category at -0.19 and for inclusive at -0.20 . We also test $\mathrm{H} 5$ in this model predicting that higher regional GDP or lower employment rates will lead to lower support for the exclusive category. GDP does have the expected effect at the regional-level but is not significant at the country level and employment rate is suggestive of this effect at the country level at -0.12 , but is not significant. In a model without GDP it is significant as they are strongly correlated, but we prefer to have both in the model to control for ability to provide welfare (GDP) and direct need of welfare (employment rate).

M5 allows individual-level SES measures to vary by group offering a test of $\mathrm{H} 4 \mathrm{a}$. We find that material security captured by education and occupation has the largest negative impact on support for the welfare state in the exclusive category, although these also have an impact for the 
conditionally inclusive category along with a much larger effect for capitalists being -0.15 less supportive. There is very little evidence of an SES effect in the inclusive category. Our preferred model, M6, adds an interaction between education and percent foreign-born at the country-level. We see that this interaction is highly significant for the exclusive group. This supports H4b suggesting that those higher in SES do not face a material security trade off with their subjective group boundaries and are far less supportive of the welfare state where there are more immigrants; however this is only true at the country-level; we tested the regional-level and it was insignificant across all groups. Interestingly we see a small but significant positive effect of this interaction for the inclusive group.

Table 5 gives model statistics. Based on the chi2 and AIC statistics, models M0-M6 each fit relatively better than the previous, suggesting that our tests are robust and our multigroup approach meaningful. However, in order to ensure that there is variation across groups we conduct slope analyses comparing the coefficients between each category of group boundary. We find that when coefficients vary (M4-M6), the impact of percent foreign-born is significantly different for the exclusive category compared with both the conditionally inclusive ("C") and inclusive ("I") categories at both the regional- and country-levels. Meanwhile its impact for the inclusive category is only significantly different from the exclusive category ("X"). Thus, immigrant presence by region and country is not significantly different in impact between conditionally inclusive and inclusive. GDP follows a similar pattern but only at the regional-level, and the effect of employment is only different between the exclusive and inclusive groups at the regional-level ${ }^{\mathrm{iv}}$.

We combine into a sheaf the derivative effects of education, occupational status, petty bourgeoisie, supervisor, vulnerable, GDP and employment in Figure 1. This provides a sense of effect sizes and allows comparison across groups. It highlights the dramatic effect predicted by $\mathrm{H} 4 \mathrm{~b}$ and shows how material self-interest and immigrant presence can work together against support for the welfare state.

\footnotetext{
iv Given that we have only 14 societies at the country-level, we are worried that we are just capturing 'noise' as opposed to significant findings. Therefore we engage in a Bayesian analysis to obtain credible intervals following the recommendation of Stegmueller (2013) with non-informative priors where gamma is 0.001 . These results identically replicate the regional-level effects of immigrant presence, and nearly reproduce the country-level effects albeit with slightly less confidence by group (inclusive at $\mathrm{p}<.001$; conditionally inclusive at $\mathrm{p}<.10$; exclusive at $\mathrm{p}<.15$ ). With 14 cases only, $85 \%$ confidence still points toward a significant impact of foreign-born as opposed to random noise in the exclusive group and offers robust support for the other two groups.
} 
Table 5. Model Statistics, Fit and Slope Tests

\begin{tabular}{|c|c|c|c|c|c|c|c|c|c|c|c|c|c|c|c|c|}
\hline Fit Statistics & M0 & M1 & M2 & M3 & \multicolumn{4}{|c|}{ M4 } & \multicolumn{4}{|c|}{ M5 } & \multicolumn{4}{|c|}{ M6 } \\
\hline log-likelihood & $-32,720$ & $-32,668$ & $-32,127$ & $-32,114$ & \multicolumn{4}{|c|}{$-32,065$} & \multicolumn{4}{|c|}{$-32,043$} & \multicolumn{4}{|c|}{$-32,033$} \\
\hline AIC & 65,449 & 65,348 & 64,285 & 64,272 & \multicolumn{4}{|c|}{64,199} & \multicolumn{4}{|c|}{64,173} & \multicolumn{4}{|c|}{64,161} \\
\hline \multirow[t]{2}{*}{ Slope Tests } & & & & & & $p$-value & & $p$-value & & $p$-value & & $p$-value & & $p$-value & & p-value \\
\hline & & & & & $b$ & by group & b & by group & b & by group & b & by group & b & by group & b & by group \\
\hline Capitalist & & & & & & & & & & & & & 0.08 & $C^{*}$ & -0.04 & \\
\hline Supervisor & & & & & & & & & & & & & -0.02 & & -0.07 & \\
\hline Vulnerable & & & & & & & & & & $C^{*}$ & & & -0.01 & & 0.06 & \\
\hline Regional Foreign-Born & & & & & 0.06 & $C^{*} ; 1^{* \star}$ & -0.12 & $X^{* *}$ & 0.07 & $C^{*} ; I^{* * *}$ & -0.13 & $X^{* * *}$ & 0.07 & $C^{* *} ;\left.\right|^{* * *}$ & -0.13 & $X^{* * *}$ \\
\hline Regional GDP & & & & & -0.10 & $C^{*} ;{ }^{\star * *}$ & 0.11 & $X^{* * *}$ & -0.11 & $C^{*} ; I^{* \star *}$ & 0.10 & $X^{* * *}$ & -0.12 & $C^{* *} ; I^{* \star *}$ & 0.11 & $X^{* * *}$ \\
\hline Regional Employment Rate & & & & & -0.01 & $1^{*}$ & -0.08 & $X^{*}$ & 0.00 & $I^{*}$ & -0.08 & $X^{*}$ & 0.00 & $1^{*}$ & -0.08 & $X^{*}$ \\
\hline individual & 0.828 & 0.824 & 0.789 & 0.789 & & 0.78 & & & & 0.7 & & & & 0.7 & 81 & \\
\hline regional & 0.033 & 0.034 & 0.030 & 0.025 & & 0.02 & & & & 0.0 & & & & & 25 & \\
\hline country & 0.147 & 0.149 & 0.133 & 0.058 & & 0.05 & & & & 0.0 & & & & & 67 & \\
\hline
\end{tabular}

NOTE: ${ }^{\mathrm{t}} \mathrm{p}<0.10$ (only for country-level) ${ }^{*} \mathrm{p}<0.05^{* \star}<0.01^{* * *} 0.001$; all models have individual $\mathrm{N}=24,604$, regional $\mathrm{N}=105$, and country $\mathrm{N}=15$. 


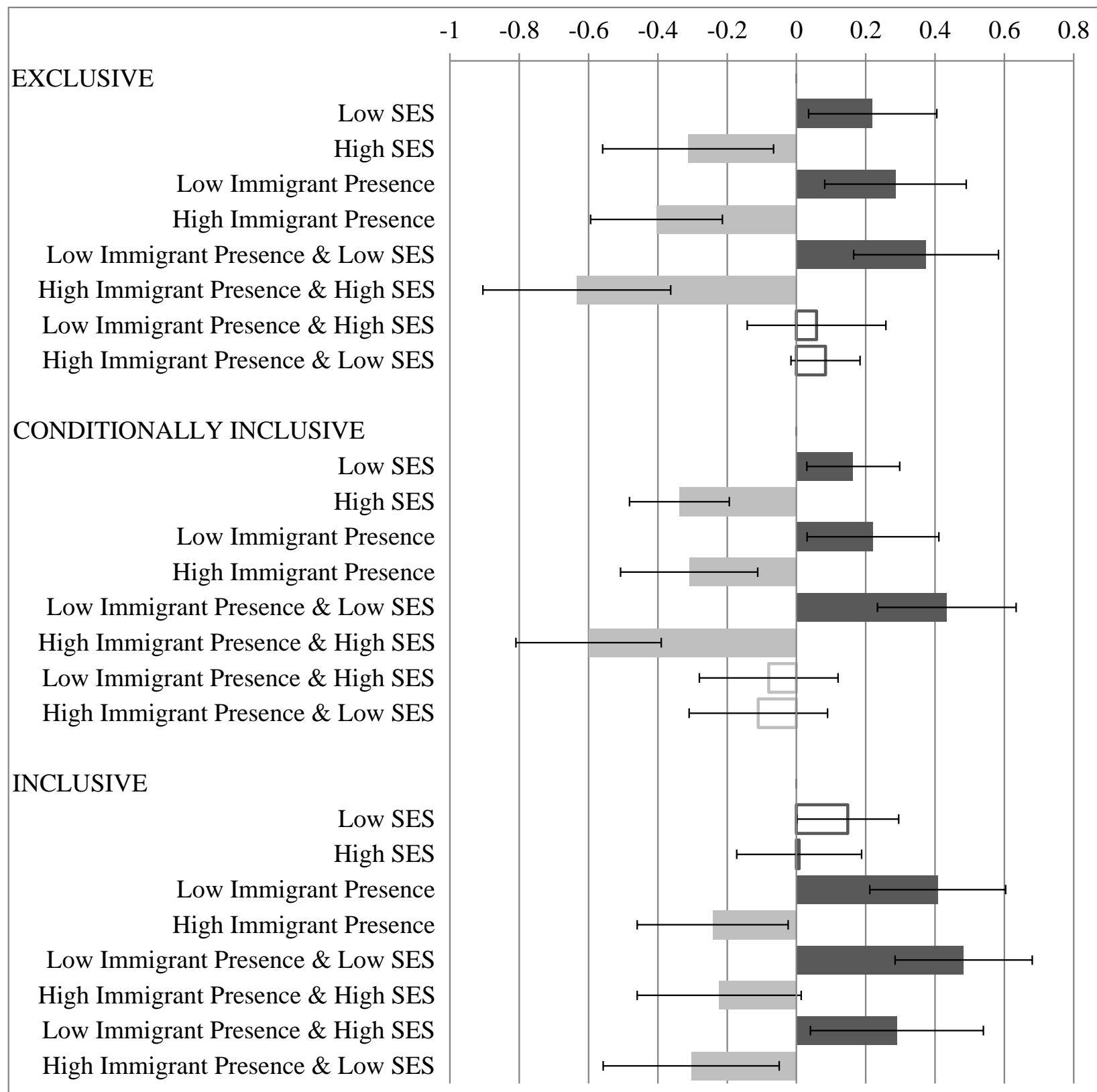

Support for the Welfare State - grand mean stdyx

Predicted margins at 1 standard deviation above and below the mean or 0 and 1 for dummyvariables show that the largest impact of SES alone occurs for the conditionally inclusive type, where almost 0.5 of a standard deviation in support for the welfare state exists between low and high SES persons, this effect is a tiny bit smaller for the Exclusive group and does not exist at all for the inclusive group. The largest impact of immigrant presence alone occurs for the exclusive group where a 0.7 standard deviations gap exists between those living in low regional and country-level 
immigrant presence versus high. However, roughly 0.6 standard deviations in support for the welfare state exists in the inclusive group, against what we hypothesized. Looking at the combined impact of immigrant presence and SES reveals that the exclusive and conditionally inclusive categories have a huge combined effect of about 1 standard deviation in welfare state support when comparing those with low SES and low immigrant presence to those with high and high respectively. This is smaller for the inclusive category at roughly 0.7 standard deviations.

\section{DISCUSSION}

We delineated natives' subjective group boundaries into three types in most western European countries. We identify individuals who prefer to have exclusive national in-group boundaries with respect to immigrants, those who will be include conditionally inclusive of immigrants only if they contribute to the state and society, and those who are unconditionally inclusive of immigrants within their national in-group boundaries. We identified that support for the welfare state is not a differently conceived attitudes across these three groups based on tests of measurement invariance ${ }^{\mathrm{v}}$. Using group dynamics and social identity theories we predicted that group boundary salience produced by increasing immigrant presence would be the highest for the exclusive type (H1). This higher salience should lead to a reduction in willingness to share group resources measured via support for the welfare state. Here we find that with respect to welfare state resources our hypotheses are true at the country-level. Countries with greater immigrant presence lead those in the exclusive category to be less supportive of the welfare state. This impact exists independent of controls for sex, age, political ideology, perceptions of current welfare policy outcomes and regional and country-level prosperity and employment. The impact of increased immigrant presence at the country-level is smaller for those in the conditionally inclusive and inclusive groups - partial support of $\mathrm{H} 2$ and H3: the impact is significantly less but does not disappear altogether. Thus group boundaries do not entirely explain the effect of immigrant presence on support for the welfare state. Immigration still has an impact for the inclusive group suggesting that their welfare state support may be negatively impacted by immigration. We speculate that their reported openness to immigrants may not be so agape. Also there may be other pathways that immigration indirectly reduces welfare state support. This should be probed in future research.

At the regional-level we found ostensibly counter-intuitive evidence. Immigrant presence has no effect for the exclusive category. It was only significant for conditionally inclusive and inclusive. Although we would like to revise our hypotheses, we were honestly surprised. We speculate that those with the most exclusive subjective group boundaries are most affected by the country-level of 
immigration. Our findings point toward this with the largest impact of immigrant presence on support for the welfare state occurring for this exclusive category $(\mathrm{H} 4 \mathrm{~b})$. This hypothesis calls for future research; however, our finding of an interaction between individual SES and immigrant presence suggests that this speculation has merit. The exclusive group under greater country-level immigrant presence is less supportive than others with less subjectively restrictive group boundaries. However, this is not true for the least educated (lowest SES) members of this exclusive group who likely struggle with a kind of trade-off between self-interest and group boundaries (e.g. Bay and Pedersen 2006). We tried a similar interaction with regional-level immigrant presence and it produced insignificant results. Thus, the significant interaction points toward the relevance of country-level immigrant presence as most salient for individuals with exclusive subjective boundaries. In addition to our Bayesian credible interval robustness check, the interaction gives support to country-level foreign-born revealing a true impact of immigrant presence, and not some 'luck' given that we have a small-N problem (Breznau forthcoming). Thus we cautiously conclude that country-level immigrant presence has a large impact on reducing suport for the welfare state, and that this varies by subjective group boundary and SES for exclusive group boundaries.

This surprising non-effect for the exclusive category at the regional-level leads us to speculate that the welfare state attitudes of those who have subjectively exclusive group boundaries are not strongly impacted by intergroup contact, and are only impacted by national-level trends as evidenced by strong anti-immigrant movements such as PEGIDA in Germany which started in Dresden where there are far less immigrants than the average in the country's other major cities. Other scholarship might help shed light on this finding. Shayo (2009) claims that the degree of national identity will decrease support for policies that target a specific class, due to national group solidarity (i.e. no one in the group should get special treatment). It is possible that more foreign-born can increase this degree (nationalism) or decrease this degree leading to a shift toward policy favoring working-class groups among those lower in SES; a claim potentially supported by our interaction of education and country-level foreign-born but not further testable in these models. Ultimately there are likely to be simultaneously conflicting effects especially given that a dualist or chauvinist welfare state is often not possible in practice although it is ideally preferred by many natives with exclusive group boundaries (Bay et al., 2013).

Our results also support a long tradition of research on material self-interest associated with support for the welfare state (H4a; H5). However, we see that material self-interest is highest for those in the exclusive and conditionally inclusive categories; i.e. the non-inclusives. We speculate that their group boundary definitions are in conflict with their need for welfare and this leads to a larger impact of SES. The desire to restrict the welfare state for everyone gives way to the desire to 
protect individual, if not familial welfare security. On the contrary, inclusive boundaries may indicate post-materialist values (Inglehart and Flanagan, 1987) or cosmopolitanism (Habermas, 2003), and such values may be steadfast despite material well-being. This might explain why those with inclusive boundaries show very little impact of SES variables on support for the welfare state. Moreover, inclusive boundaries want to reduce resource sharing under greater regional immigrant presence, suggesting that their agape, redistributive attitudes might be susceptible to change given contact. Perhaps the most inclusive and open attitudes belong to persons who are more gated from experiencing contact with immigrants. They may change their support for the welfare state with increased immigrant presence as easily as exclusive boundary types of persons who experience material hardship.

Theoretically our analysis provides an empirical application of group boundary salience leading to in-group bias, although we see our findings as supporting this theoretically causal mechanism, we do not wish to overstate causality as it is currently understood in statistical terms (Pearl 2009; Antonakis et al. 2010). Our evidence nonetheless is supportive of what we see as sound theoretical reasoning: Group boundary mechanism might be as powerful as a material self-interest in shaping support for the welfare state. Furthermore, self-interest is especially tricky when it comes to those with subjectively exclusive boundaries who face a trade-off between material security and preventing redistribution to or acceptance of immigrants. So long as those with exclusive subjective group boundaries remain a marginal slice of the overall European welfare states' populations, we do not expect that support for the welfare state will dissolve given continued increases in immigration, but activating group boundaries can come in a variety of forms and holds the ominous potential to undermine welfare state support among the non-exclusives as well, and could lead to chauvinistic welfare state policies.

Our results contribute to theories of welfare state retrenchment. Individuals in Western Europe live in countries consisting of anywhere from 4 to $28 \%$ foreign-born immigrants, and within those countries reside in regions with 2 to $38 \%$ foreign-born. The more immigrants visible or known to be present within natives' national borders, the more likely that group boundaries become salient and support for the welfare state may wane; as it turns out this may be true even for those proclaiming to have inclusive group boundaries. After the prosperous 'golden era' of European welfare states ending sometime between 1980 and 2000 in most countries, neoliberal agendas and conditions of permanent austerity are retrenching social policies (Pierson, 2002). Welfare state dismantling comes in general at the hands of both right and left parties, despite right parties taking a much stronger oppositional position (Schumacher et al., 2013). The power gains of right parties in general over the past decades are due in part to the rise of anti-immigrant parties who now regularly 
hold 10-25\% of European parliaments since 2000, except for Ireland and Germany. Most of these parties have a 'radical-right' agenda, and those who are not far out, are at least partway out to the right (Mudde, 2013). Mobilizing welfare chauvinism and anti-immigrant rhetoric (Eger and Valdez 2015), anti-immigrant parties unanimously form coalitions with right and right-center parties who traditionally target welfare. This is another part of the story of welfare state retrenchment at the turn of the millennium. However, this conclusion is limited by the cross-sectional nature of our data. We look forward to the next round of the ESS in 2016 to analyze changes in immigrant presence.

\footnotetext{
${ }^{\vee}$ We relied on a single question for determining the definition of national group boundaries and have reason to believe that the full range of complexities of national group identity are not fully captured (Alwin, 1989; Kaufmann, 2008).
} 


\section{E. REFERENCES}

Allport GW (1954) The Nature of Prejudice. Cambridge, MA: Addison-Wesley.

Alwin D (1989) Problems in the Estimation and Interpretation of the Reliability of Survey Data. Quality and Quantity, 23(3-4), 277-331.

Andreß H-J, Golsch K and Schmidt AW (2013) Applied Panel Data Analysis for Economic and Social Surveys. Berlin, Heidelberg: Springer.

Arts W and Gelissen J (2001) Welfare States, Solidarity and Justice Principles: Does the Type Really Matter? Acta Sociologica, 44(4), 283-299.

Baron RM and Kenny DA (1986) The Moderator-Mediator Variable Distinction in Social Psychological Research: Conceptual, Strategic, and Statistical Considerations. Journal of Personality and Social Psychology, 51(6), 1173-1182.

Bay A-H and Pedersen AW (2006) The Limits of Social Solidarity: Basic Income, Immigration and the Legitimacy of the Universal Welfare State. Acta Sociologica, 49(4), 419-436.

Bay A-H, Finseraas H and Pedersen AW (2013) Welfare Dualism in Two Scandinavian Welfare States: Public Opinion and Party Politics. West European Politics, 36(1), 199-220.

Bean C and Papadakis E (1998) A Comparison of Mass Attitudes towards the Welfare State in Different Institutional Regimes, 1985-1990. International Journal of Public Opinion Research, 10(3), 211-236.

Blekesaune M and Quadagno J (2003) Public Attitudes toward Welfare State Policies: A Comparative Analysis of 24 Nations. European Sociological Review, 19(5), 415-427.

Bobo L and Licari FC (1989) Education and Political Tolerance: Testing the Effects of Cognitive Sophistication and Target Group Affect. The Public Opinion Quarterly, 53(3), 285-308.

Boeri T (2010) Immigration to the Land of Redistribution. Economica, 77(308), 651-687.

Bourdieu P (1984) Distinction: A Social Critique of the Judgement of Taste. London: Routledge.

Brader T, Valentino NA and Suhay E (2008) What Triggers Public Opposition to Immigration? Anxiety, Group Cues, and Immigration Threat. American Journal of Political Science, 52(4), 959-978.

Brady D (2009) Rich Democracies, Poor People. How Politics Explains Poverty. Oxford University Press.

Brady D and Finnigan R (2014) Does Immigration Undermine Public Support for Social Policy? American Sociological Review, 79 (1), 17-42.

Brewer MB (1979) In-Group Bias in the Minimal Intergroup Situation: A Cognitive-Motivational Analysis. Psychological Bulletin, 86(2), 307-324.

Breznau, N (2010) Economic Equality and Social Welfare: Policy Preferences in Five Nations. International Journal of Public Opinion Research 22(4), 458-484.

Breznau, N (forthcoming) Secondary Observer Effects: Idiosyncratic Errors in Small-N Secondary Data Analysis. International Journal of Social Research Methodology. Online first. 
Brubaker R (1996) Nationalism Reframed: Nationhood and the National Question in the New Europe. Cambridge: Cambridge University Press.

Burgoon B, Koster F and van Egmond M (2012) Support for Redistribution and the Paradox of Immigration. Journal of European Social Policy, 22(3), 288-304.

Castles FG and Miller MJ (2003) The Age of Migration. Third. New York: Guilford Press.

Dahlberg M, Edmark K and Lundqvist H (2012) Ethnic Diversity and Preferences for Redistribution. Journal of Political Economy, 120(1), 41-76.

Dallinger U (2010) Public Support for Redistribution: What Explains Cross-National Differences? Journal of European Social Policy, 20(4), 333-349.

Davidov E, Dülmer H, Schlüter E, et al. (2012) Using a Multilevel Structural Equation Modeling Approach to Explain Cross-Cultural Measurement Noninvariance. Journal of Cross-Cultural Psychology, 43 (4), $558-575$.

Eger MA (2010) Even in Sweden: The Effect of Immigration on Support for Welfare State Spending. European Sociological Review, 26(2), 203-217.

Eger, MA, and S Valdez (2015) Neo-Nationalism in Western Europe. European Sociological Review $31(1), 115-130$.

Eurostat. (2014). Employment rates by NUTS region (\%), [lfst_r_lfe2emprt]. Database: Regional employment - LFS annual series. Data extracted on April 10, 2014.

ESS (2008) European Social Survey Round 4. Stata Readable Datafile: European Social Survey.

Evans MDR and Kelley J (2002) National Pride in the Developed World: Survey Data from 24 Nations. International Journal of Public Opinion Research , 14 (3 ), 303-338.

Festinger L (1954) A Theory of Social Comparison Processes. Human Relations, 7(2), 117-140.

Finseraas H (2012) Poverty, Ethnic Minorities among the Poor, and Preferences for Redistribution in European Regions. Journal of European Social Policy, 22(2), 164-180.

Fox C (2004) The Changing Color of Welfare? How Whites' Attitudes toward Latinos Influence Support for Welfare. The American Journal of Sociology, 110(3), 580-625.

Ganzeboom HBG, De Graaf PM and Treiman DJ (1992) A Standard International Socio-Economic Index of Occupational Status. Social Science Research, 21(1), 1-56.

Habermas J (2003) Toward a Cosmopolitan Europe. Journal of Democracy, 14(4), 86-100.

Hasenfeld Y and Rafferty JA (1989) The Determinants of Public Attitudes toward the Welfare State. Social Forces, 67(4), 1027-1048.

Hjerm M (2009) Anti-Immigrant Attitudes and Cross-Municipal Variation in the Proportion of Immigrants. Acta Sociologica, 52(1), 47-62.

Hjerm M and Schnabel A (2012) How much Heterogeneity can the Welfare State Endure? The Influence of Heterogeneity on Attitudes to the Welfare State. Nations and Nationalism, 18(2), 346-369. 
Hogg MA and Turner JC (1987) Intergroup Behaviour, Self-Stereotyping and the Salience of Social Categories. British Journal of Social Psychology, 52(4), 325-340.

Hox JJ (1995) Applied Multilevel Analysis. Amsterdam: TT-Publikaties.

Huber JD (1989) Values and Partisanship in Left-Right Orientations: Measuring Ideology. European Journal of Political Research, 17(5), 599-621.

Inglehart R and Flanagan SC (1987) Value Change in Industrial Societies. The American Political Science Review, 81(4), 1289-1319.

Jæger MM (2006) What Makes People Support Public Responsibility for Welfare Provision: Self-interest or Political Ideology? A Longitudinal Approach. Acta Sociologica, 49(3), 321-338.

Kaufmann E (2008) The Lenses of Nationhood: An Optical Model of Identity. Nations and Nationalism, Blackwell Publishing Ltd, 14(3), 449-477.

Kelley J (1990) The Failure of a Paradigm: Log-linear Models of Social Mobility. In: Clark J, Modgil C, and Modgil S (eds), John H. Goldthorpe: Consensus and Controversy, London: Falmer, pp. 319-346.

Kenworthy L (2004) Egalitarian Capitalism. New York: Russell Sage Foundation.

Lamont M and Molnár V (2002) The Study of Boundaries in The Social Sciences. Annual Review of Sociology, 28(1), 167-195.

Landerman, LR, KC Land, and CF Pieper (1997) An Empirical Evaluation of the Predictive Mean Matching Method for Imputing Missing Values. Sociological Methods \& Research 26(1):3-33.

Luttmer EFP (2001) Group Loyalty and the Taste for Redistribution. Journal of Political Economy, 109(3), $500-528$.

Mau S and Burkhardt C (2009) Migration and Welfare State Solidarity in Western Europe. Journal of European Social Policy, 19(3), 213-229.

Mau S, Mewes J and Zimmermann A (2008) Cosmopolitan Attitudes through Transnational Social Practices? Global Networks, 8(1), 1-24.

Mudde C (2013) Three Decades of Populist Radical Right Parties in Western Europe: So What? European Journal of Political Research, 52(1), 1-19.

Mullen B, Brown R and Smith C (1992) Ingroup Bias as a Function of Salience, Relevance, and Status: An Integration. European Journal of Social Psychology, 22(2), 103-122.

Nannestad P (2007) Immigration and Welfare States: A Survey of 15 Years of Research. European Journal of Political Economy, 23(2), 512-532.

OECD (2009) Society at a Glance 2009: OECD Social Indicators.

OECD (2012) Social Expenditures Database. www.oecd.org, accessed 01.10.2012: Organization for Economic Cooperation and Development.

Pedhazur EJ (1997) Multiple Regression in Behavioral Research: Explanation and Predicton. New York: Harcourt Brace. 
Pfeifer M (2009) Public Opinion on State Responsibility for Minimum Income Protection: A Comparison of 14 European Countries . Acta Sociologica, 52 (2), 117-134.

Pierson P (2002) Coping with Permanent Austerity: Welfare State Restructuring in Affluent Democracies. Revue française de sociologie, 43(2), 369-406.

Pierson P and Leibfried S (1995) Multitiered Institutions and the Making of Social Policy. In: Leibfried S and Pierson P (eds), Euroean Social Policy: Between Fragmentation and Integration, Washington D.C.: The Brookings Institution, pp. 1-40.

Price V (1989) Social Identification and Public Opinion: Effects of Communicating Group Conflict. The Public Opinion Quarterly, 53(2), 197-224.

Putnam RD (2007) E Pluribus Unum: Diversity and Community in the Twenty-First Century: The 2006 Johan Skytte Prize Lecture. Scandinavian political studies, 30(2), 137-174.

Reeskens T and Wright M (2013) Nationalism and the Cohesive Society: A Multilevel Analysis of the Interplay Among Diversity, National Identity, and Social Capital Across 27 European Societies . Comparative Political Studies , 46 (2 ), 153-181.

Reicher S (2004) The Context of Social Identity: Domination, Resistance, and Change. Political Psychology, 25(6), 921-945.

Renan E (1882) Qu'est-ce qu'une nation. Ourves Completes, I(Paris, 1947), 887-907.

Roosma F, Gelissen J and van Oorschot W (2013) The Multidimensionality of Welfare State Attitudes: A European Cross-National Study. Social Indicators Research, 113(1), 235-255.

Roosma F, van Oorschot W and Gelissen J (2014) The Preferred Role and Perceived Performance of the Welfare State: European Welfare Attitudes from a Multidimensional Perspective. Social science research, 44C, 200-210.

Schumacher G, Vis B and van Kersbergen K (2013) Political Parties' Welfare Image, Electoral Punishment and Welfare State Retrenchment. Comparative European Politics, 11(1), 1-21.

Stegmueller D (2013). How Many Countries for Multilevel Modeling? A Comparison of Frequentist and Bayesian Approaches. American Journal of Political Science, 57(3), 748-761.

Svallfors S (1997) Worlds of Welfare and Attitudes to Redistribution: A Comparison of Eight Western Nations. European Sociological Review, 13(3), 283-304.

Tajfel H (1970) Experiments in Intergroup Discrimination. Scientific American, (November), 96-102.

Tajfel H (1982) Social Psychology of Intergroup Relations. Annual Review of Psychology, Annual Reviews, 33(1), 1-39.

Tajfel H and Turner JC (1979) An Integrative Theory of Intergroup Conflict. In: Austin WG and Worchel S (eds), The Social Psychology of Intergroup Relations, Monterey, CA: Brooks-Cole, p. 49.

Tajfel H, Billig MG, Bundy RP, et al. (1971) Social Categorization and Intergroup Behaviour. European Journal of Social Psychology, 1(2), 149-178.

Taylor-Gooby P (2001) Sustaining State Welfare in Hard Times: Who will Foot the Bill? Journal of European Social Policy, 11(2), 133-147. 
Taylor-Gooby P (2011) Security, Equality and Opportunity: Attitudes and the Sustainability of Social Protection. Journal of European Social Policy, 21(2), 150-163.

Turner JC (1975) Social Comparison and Social Identity: Some Prospects for Intergroup Behaviour. European Journal of Social Psychology, 5(1), 1-34.

Van de Schoot R, Lugtig P and Hox J (2012) A Checklist for Testing Measurement Invariance. European Journal of Developmental Psychology, 9(4), 486-492.

Van Oorschot W (2006) Making the Difference in Social Europe: Deservingness Perceptions Among Citizens of European Welfare States. Journal of European Social Policy, 16(1), 23-42.

Van Oorschot W and Meuleman B (2012) Welfarism and the Multidimensionality of Welfare State Legitimacy: Evidence from The Netherlands, 2006. International Journal of Social Welfare, 21(1), 79 93.

Wlezien C (1995) The Public as Thermostat: Dynamics of Preferences for Spending. American Journal of Political Science, 39(4), 981-1000. 
Appendix Table A1. Regional Database Construction

\begin{tabular}{|c|c|c|c|c|c|c|c|c|c|}
\hline Country & NUTS $^{\wedge}$ & Geo Unit & Count & Year & Sol & urces & Accessed & Mean & SD \\
\hline Belgium & 1 & $\begin{array}{l}\text { Gewesten/ } \\
\text { Régions }\end{array}$ & 3 & 2007 & Stat Bel & http://statbel.fgov.be & Apr 11 & 20.55 & 18.38 \\
\hline Denmark & 2 & Regioner & 5 & 2008 & Statistics Denmark & http://www.dst.dk & Mai 11 & 6.23 & 2.54 \\
\hline Finland & 2 & Suuralueet & 4 & 2008 & Statistics Finland & http://www.stat.fi & Jun 11 & 3.24 & 1.63 \\
\hline France & 1 & ZEAT & 8 & 2005 & $\begin{array}{c}\text { National Institute of } \\
\text { Statistics and } \\
\text { Economic Studies }\end{array}$ & http://www.insee.fr & & 10.38 & 5.65 \\
\hline Germany (East) & 1 & Länder & 6 & 2007 & German Microcensus & $\begin{array}{c}\text { https://www.regionalst } \\
\text { atistik.de/ }\end{array}$ & Apr 11 & 5.89 & 5.20 \\
\hline Germany (West) & 1 & Länder & 11 & 2007 & German Microcensus & $\begin{array}{c}\text { https://www.regionalst } \\
\text { atistik.de/ }\end{array}$ & Apr 11 & 14.53 & 3.10 \\
\hline Greece & 2 & Perifereies & 10 & $2001^{\circ}$ & $\begin{array}{c}\text { Hellenic Statistical } \\
\text { Authority }\end{array}$ & http://www.statistics.gr & Jun 11 & 6.52 & 2.40 \\
\hline Ireland & $3^{*}$ & $\begin{array}{l}\text { Regional } \\
\text { Authorities }\end{array}$ & 5 & 2005 & $\begin{array}{l}\text { Ireland's Central } \\
\text { Statistics Office }\end{array}$ & http://www.cso.ie & Apr 11 & 16.30 & 2.31 \\
\hline Netherlands & 2 & Provincies & 12 & 2007 & $\begin{array}{c}\text { Centraal Bureau voor } \\
\text { de Statistiek }\end{array}$ & http://statline.cbs.nl & Apr 11 & 9.20 & 3.74 \\
\hline Norway & 2 & Regioner & 7 & 2008 & Stat Nord & $\begin{array}{c}\text { https://www.h2.scb.se/ } \\
\text { grs/ }\end{array}$ & Jun 11 & 8.97 & 4.05 \\
\hline Spain & & $\begin{array}{l}\text { Comunidades y } \\
\text { ciudades }\end{array}$ & 18 & 2007 & $\begin{array}{c}\text { Instituto Nacional de } \\
\text { Estadística }\end{array}$ & http://www.ine.es & Jun 11 & 9.45 & 4.75 \\
\hline Sweden & 2 & Riksområden & 8 & 2007 & Statistics Sweden & http://www.ssd.scb.se/ & Apr 11 & 11.50 & 4.59 \\
\hline Switzerland & 2 & Regionen & 7 & 2010 & $\begin{array}{l}\text { Federal Swiss } \\
\text { Statistics }\end{array}$ & $\begin{array}{c}\text { http://www.pxweb.bfs.a } \\
\text { dmin.ch }\end{array}$ & Apr 12 & 27.32 & 6.84 \\
\hline UK & 1 & Regions & 12 & 2007 & $\begin{array}{l}\text { Office for National } \\
\text { Statistics }\end{array}$ & $\begin{array}{c}\text { http://www.statistics.g } \\
\text { ov.uk }\end{array}$ & Apr 11 & 9.02 & 7.81 \\
\hline
\end{tabular}

*Ireland's 8 units collapsed into 5 in ESS

${ }^{\circ}$ Greece only published percent foreign citizen, which is the proportion of the population born abroad excluding immigrants who have naturalized. We impute using the ESS sampling design which has a near perfect match between the rate of immmigrants sampled and their actual rate by region in all the other countries.

^NUTS 1: Pop = 3-7 million; NUT S 2: Pop = 800,000-2.99 million; NUT 3: Pop = 150,000-799, 999 